[Original]

\title{
Continuous Monitoring of Changes in Blood Volume and Limb Volume During Lower Body Negative Pressure
}

\author{
Fumio Yamazaki ${ }^{1}$, Keizo ShIRAKI, ${ }^{2}$ Yutaka Endo ${ }^{3}$ and Sueko SAGaWA ${ }^{4}$ \\ 'Department of Clinical Pathophysiology, School of Health Sciences, University of Occupational and \\ Environmental Health, Japan. Yahatanishi-ku, Kitakyushu 807-8555, Japan \\ ${ }^{2}$ Department of Physiology, School of Medicine, University of Occupational and Environmental \\ Health, Japan. Yahatanishi-ku, Kitakyushu 807-8555, Japan \\ ${ }^{3}$ School of Health Sciences, International University of Health and Welfare. Odawara, Kanagawa \\ 250-8588, Japan \\ ${ }^{4}$ School of Sport Sciences, Kyushu Kyoritsu University. Yahatanishi-ku, Kitakyushu 807-8585, Japan
}

Abstract: Lower body negative pressure (LBNP) induces venous pooling in the legs and a decrease of blood volume (BV). The present study was designed to investigate the dynamic changes in BV and limb volume during LBNP. We made continuous measurements of blood density $\left(\rho_{\mathrm{b}}\right)$ during LBNP at two different levels (15 and $-30 \mathrm{mmHg}$ ) in eight healthy male volunteers. Blood was withdrawn continuously from the antecubital vein to measure $\rho_{\mathrm{b}}$ during an experimental period of $40 \mathrm{~min}$ (a 10-min control period, a 10-min LBNP and a 20-min recovery period). The density was measured by the mechanical oscillator technique. The changes of circumference in the upper arm and calf were measured by strain gauge plethysmography. $\quad \rho_{\mathrm{b}}$ decreased rapidly in the early phase of LBNP followed by an increase, as expected. The peak reduction $(-0.35 \pm 0.04 \mathrm{~g} / \ell)$ of $\rho_{\mathrm{b}}$ at $-15 \mathrm{mmHg}$ did not differ $(P=0.47)$ from that $(-0.42 \pm 0.05 \mathrm{~g} / \ell)$ at $-30 \mathrm{mmHg}$. The time $(2.9 \pm 0.3 \mathrm{~min})$ from onset of LBNP to the peak reduction of $\rho_{b}$ was not significantly different between -15 and $-30 \mathrm{mmHg}(P$ $=0.50)$. After LBNP, a further $\rho_{\mathrm{b}}$ increase was continued for $2.5 \pm 0.2 \mathrm{~min}$ at both intensities, followed by the return toward control levels. The maximal increase $(1.34 \pm 0.07 \mathrm{~g} / \ell)$ of $\rho_{\mathrm{b}}$ after LBNP at $-30 \mathrm{mmHg}$ was greater $(P<0.001)$ than that $(0.57 \pm 0.06 \mathrm{~g} / \ell)$ at $-15 \mathrm{mmHg}$. LBNP decreased the arm circumference and increased the calf circumference in an intensity-dependent manner. These results suggest that LBNP induces an intensity-dependent decrease in BV with no difference in the time peak reduction occurring after LBNP. We found no significant difference between the intensities in the transient hemodilution effect during LBNP. It is suggested that LBNP also induces an intensitydependent mobilization of blood from the upper portion to the lower portion of the body.

Key words : blood density, plasma density, blood volume, gravitational stress, fluid absorption.

(Received 25 May 2007, accepted 18 July 2007) 


\section{Introduction}

Lower body negative pressure (LBNP) has been used extensively as a research tool to study circulatory response to gravitational stress [1-4]. LBNP has two effects on the mobilization of blood in humans: first, a redistribution of blood from the cranial portion to the inferior portion of the body, resulting in a decreased central blood volume and venous pooling in the legs, and second, a filtration of fluid through capillary walls, resulting in a decreased circulating plasma volume (PV). For example, a 10-min LBNP of $-70 \mathrm{mmHg}$ decreased PV by about $490 \mathrm{ml}$ [5]. With regard to the decrease in PV due to LBNP, Loeppky et al. [6] showed a further reduction in PV at $1-3$ min after LBNP by using estimates of PV based on changes in hematocrit (Hct) and hemoglobin. They pointed out that the sampling time was an important factor in the estimation of PV changes during and after LBNP. Although continuous monitoring of PV or blood volume (BV) during LBNP provides useful information for understanding the dynamics of fluid shift during gravitational stress, these are poorly understood due to technical limitations. To the best of our knowledge, only one report is available on continuous changes in BV during LBNP [7]. Hinghofer-Szalkay et al. [7] examined continuous changes in the density $\left(\rho_{\mathrm{b}}\right)$ of blood withdrawn from the antecubital vein to explore detailed changes in BV by using blood densitometry during LBNP of $-35 \mathrm{mmHg}$. The densitometry technique has high resolution, allows rapid measurement, and detects changes with a small blood sample $(0.1 \mathrm{ml})[8-10]$. They reported that LBNP caused microvascular fluid gain (hemodilution) preceding fluid loss (hemoconcentration) during LBNP. As a cause of early hemodilution, a reduction in capillary pressure as a consequence of precapillary vasoconstriction during LBNP may cause an inward shift of fluid from the extravascular space in the upper limbs [7]. The hemodilution caused by the reflex vasoconstriction in the human arm constitutes an important component in the overall cardiovascular compensatory adjustments to reduced circulating BV during LBNP [11]. Thus, we hypothesized that early hemodilution may depend on the magnitude of the vasoconstrictor responses that are changed by the LBNP intensity. The LBNP-induced hemoconcentration may be also intensity-dependent because of a change in the balance of Starling forces, but the effect of the intensity on the hemoconcentration dynamics is still unknown.

Accordingly, the present study was designed in humans 1) to further understand the changes in BV over a short interval or continuously and 2) to examine the effect of different levels of LBNP on the changes in BV during and after LBNP. To achieve these experimental objectives, $\rho_{\mathrm{b}}$, plasma density $\left(\rho_{\mathrm{p}}\right)$, and Hct were measured by continuous blood sampling during LBNP at light $(-15 \mathrm{mmHg})$ and moderate $(-30 \mathrm{mmHg})$ intensities. Moreover, to explore the change in blood distribution between the upper and lower body, we measured cardiovascular variables, including volume changes in the upper and lower limbs, during LBNP. 


\section{Methods}

\section{Subjects}

Eight normal healthy male volunteers $(22 \pm 1 \mathrm{yr}, 65.9 \pm 2.6 \mathrm{~kg}$ body wt, $173 \pm 3 \mathrm{~cm}$ tall) were selected for this study. The day before each experiment the subjects refrained from eating and drinking after 22:00 $\mathrm{h}$ until the experiment was completed. The experiments were approved by the Ethics Committee of Medical Care and Research of the University of Occupational and Environmental Health, and all subjects gave their written consent to participate after being fully informed about the procedures, risks and protocol.

\section{Measurements}

Mass density [mass per unit volume $(\mathrm{g} / \ell)$ ] of the samples was measured by the mechanical oscillator technique, which is based on high-resolution oscillation-time determinations using the mass spring principle [8, 9]. Briefly, the resonant frequency of an oscillating Ushaped glass tube was determined by electromagnetic means and converted to the corresponding density value. The system was calibrated before measurements with air and distilled water of known density. A density-measuring apparatus (DMA602M, Anton Paar KG, Graz) requiring a $0.1 \mathrm{ml}$-sample volume and a DMA-60 calculating unit was used. The surface of the measuring cell was coated with silicone (SurfaSil, Pierce Chemical, Rockford). Because densitometry is temperature sensitive, all density determinations were performed at $37.0^{\circ} \mathrm{C}$ with a precise thermostat (Ultrathermostat Model CB7, Heto, Allerod). Continuous blood densitometry with 5 -s monitoring was performed at a flow rate of $1.3 \mathrm{ml} / \mathrm{min}$ using a constant-flow roller pump (STC508, Terumo, Tokyo). Sodium heparin (1000 units $/ \mathrm{ml}$ ) was infused into the blood sampling tube through a three-way stopcock at a rate of $0.5 \mathrm{ml} / \mathrm{h}$ using a microsyringe pump (Model 100, KD Scientific, Boston) $[12,13]$. The decrease in $\rho_{\mathrm{b}}$ caused by the admixture of the heparin solution was negligible (less than $0.3 \mathrm{~g} / \ell$ ). The dilution effect due to the addition of the heparin solution was not corrected in the present study. The time delay due to the dead space between the tip of the venous cannula and densitometry cell was $90 \mathrm{~s}$. This time delay was corrected for later analyses.

Because the blood samples passed intact through the measuring cell, blood was pooled in sampling tubes every $2 \mathrm{~min}$ and $\rho_{\mathrm{p}}$ and Hct were measured. $\rho_{\mathrm{p}}$ was measured with the same densitometer after centrifugation of the 2-min pooled blood. Hct values were determined in triplicate by centrifugation (5 min, 11,000 rpm). Raw Hct values were corrected for an estimated $4 \%$ trapped plasma.

Mean arterial pressure (MAP) was measured continuously from a cuff on the middle finger (Finapres, Ohmeda, Madison, WI). Cardiac output (CO) was measured continuously with an impedance cardiography (PA1100, NEC, Gunma) with the standard four-band electrode arrangement [14]. Changes in circumference in the right upper arm and right calf from the control value caused by LBNP were determined using a gauge made of highly elastic tubing filled with mercury. The gauges were placed at the center of the upper arm and the maximum calf girth. The cardiovascular variables, including changes in limb circumference, were recorded by a data logger (DE1200 universal, NEC Sanei, Tokyo, Japan) every $5 \mathrm{~s}$ 
and averaged every 2 min.

\section{Procedure}

On the experimental day, each subject reported to the laboratory at 09:30 h. In a climatic chamber $\left(28^{\circ} \mathrm{C}\right.$ ambient temperature, $\mathrm{Ta} ; 60 \%$ relative humidity), the subjects wore trunks and entered the LBNP device. For about $1 \mathrm{~h}$, the subjects lay supine while being instrumented for measurements of $\rho_{\mathrm{b}}$, blood pressure, circumference of limbs and CO. A 3.2cm 18-gauge intravascular over-the-needle Teflon catheter (Vasculon 2, Ohmeda, Helsingborg) was then inserted into the left antecubital vein. After measurements were made for a 10 min control period, the subject was exposed to -15 or $-30 \mathrm{mmHg}$ of LBNP for $10 \mathrm{~min}$, which was followed by a 20 -min recovery period. The external negative pressure was produced within $10 \mathrm{~s}$. Each subject was tested at two different intensities of LBNP. There was an interval of at least seven days between experiments, and the order of treatments was randomized.

\section{Calculations and Data Analysis.}

Circulating erythrocyte density $\left(\rho_{\mathrm{e}}\right)$ was computed from $\rho_{\mathrm{p}}, \rho_{\mathrm{b}}$ and Hct [15]. Total peripheral resistance (TPR) was calculated from MAP and CO. In the calculation of stroke volume by impedance cardiography, the change of $\rho_{\mathrm{b}}$ was not corrected. LBNP evoked initial rapid changes in arm and calf volume (i.e. venous capacitance response) followed by slower changes due to net transcapillary fluid shift [5]. Since the capacitance response was completed within 3 min of starting LBNP [5], we defined the response as the circumference change in the initial $3 \mathrm{~min}$ of LBNP. The rate of filtration was estimated from the circumference changes between 3 and 10 min of LBNP.

Results are expressed as means $\pm \mathrm{SE}$. Baseline control values were calculated from the data of the 10-min control period. Comparison of the data was made by a two-way ANOVA for repeated measurements. When significant $F$ ratios were obtained, the least significant differences were calculated for comparisons between means. Significant differences between corresponding LBNP tests at different intensities were determined by Student' paired $t$ test. In all statistical tests, $P<0.05$ was considered significant.

\section{Results}

\section{Density and Hct}

The average values of $\rho_{\mathrm{b}}(1047.9 \pm 0.5 \mathrm{~g} / \ell), \rho_{\mathrm{p}}(1018.6 \pm 0.1 \mathrm{~g} / \ell)$, Hct $(43.3 \pm 0.6 \%)$, and $\rho_{\mathrm{e}}(1086.4 \pm 0.5 \mathrm{~g} / \ell)$ during the control period were not significantly different between the two LBNP conditions. Figure 1 shows continuous recordings of changes in $\rho_{b}$ during the course of the experiments. After the initiation of LBNP, $\rho_{\mathrm{b}}$ decreased immediately and reached a nadir. The time from the onset of LBNP to the nadir did not differ $(P=0.50)$ between LBNP of $-15(2.8 \pm 0.5 \mathrm{~min})$ and of $-30 \mathrm{mmHg}(3.0 \pm 0.4 \mathrm{~min})$. The maximal reduction in $\rho_{\mathrm{b}}$ during LBNP at $-15 \mathrm{mmHg}(-0.35 \pm 0.04 \mathrm{~g} / \ell)$ did not differ $(P=0.47)$ from that at $-30 \mathrm{mmHg}(-0.42 \pm 0.05 \mathrm{~g} / \ell)$. After the initial reduction, the subsequent increase in 
A

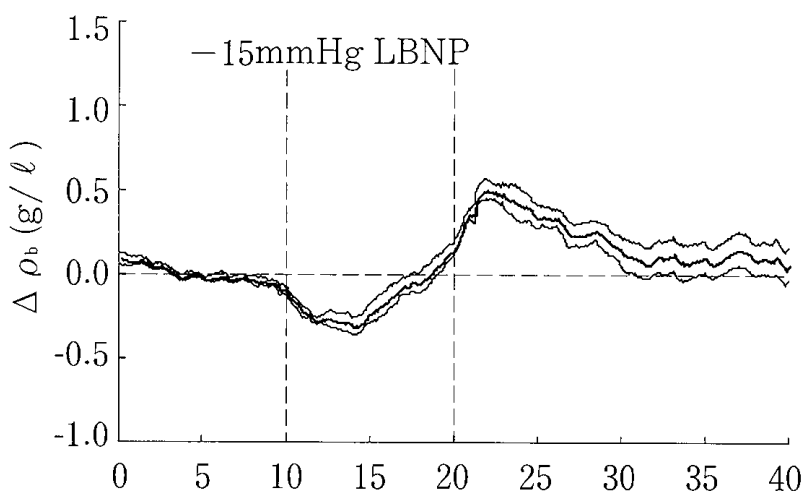

$\mathrm{B}$

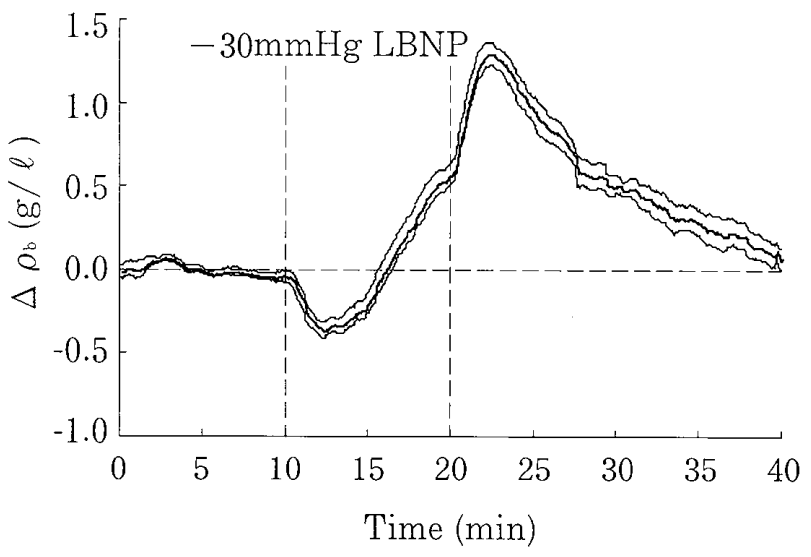

Fig. 1. Continuous changes in blood density $\left(\rho_{\mathrm{b}}\right)$ during lower body negative pressure (LBNP) at -15 (A) and -30 $\mathrm{mmHg}(\mathrm{B})$. Thick lines with upper and lower thin lines indicate mean $\pm \mathrm{SE}(\mathrm{n}=8)$.

$\rho_{\mathrm{b}}$ accelerated after termination of LBNP and reached a zenith at $2.4 \pm 0.4$ and $2.5 \pm 0.1 \mathrm{~min}$ after LBNP at -15 and $-30 \mathrm{mmHg}(P=0.80 \mathrm{vs}-15 \mathrm{mmHg})$, respectively. The maximal increase in $\rho_{\mathrm{b}}$ after LBNP at $-30 \mathrm{mmHg}(1.34 \pm 0.07 \mathrm{~g} / \ell)$ was greater $(P<0.001)$ than that at $-15 \mathrm{mmHg}(0.57 \pm 0.06 \mathrm{~g} / \ell)$. After that, $\rho_{b}$ decreased slowly to the control level.

$\rho_{\mathrm{p}}$ decreased transiently $(P<0.05)$ at the start of LBNP of $-30 \mathrm{mmHg}$, but not of -15 $\mathrm{mmHg}$. The subsequent increase in $\rho_{\mathrm{p}}$ during LBNP continued to the third min after LBNP and then decreased slowly to the pre-LBNP levels. The maximal increase in $\rho_{\mathrm{p}}$ after LBNP at $-30 \mathrm{mmHg}(0.65 \pm 0.04 \mathrm{~g} / \ell)$ was greater $(P<0.05)$ than that at $-15 \mathrm{mmHg}(0.22 \pm 0.03$ $\mathrm{g} / \ell)$. In the same way as $\rho_{\mathrm{p}}$, Hct decreased transiently $(P<0.05)$ in the initial phase of LBNP of $-30 \mathrm{mmHg}$, but not of $-15 \mathrm{mmHg}$, followed by an increase. The increase in Hct reached a peak at one min after LBNP and then decreased slowly to the pre-LBNP levels. The maximal increase in Hct after LBNP at $-30 \mathrm{mmHg}(1.25 \pm 0.13 \%)$ was greater $(P<0.05)$ than that at $-15 \mathrm{mmHg}(0.53 \pm 0.16 \%)$. Computed $\rho_{\mathrm{e}}$ was not significantly changed by LBNP. 


\section{Changes in cardiovascular variables}

Figure 2 shows changes in the circumference in the upper arm and calf during the course of the experiments. LBNP decreased the arm circumference and increased the calf circumference in an intensity-dependent manner. The rapid decrease (i.e. capacitance response) in arm circumference during LBNP at $-30 \mathrm{mmHg}(-0.086 \pm 0.015 \%)$ was greater $(P=0.003)$ than that at $-15 \mathrm{mmHg}(-0.052 \pm 0.010 \%)$. Moreover, the rapid increase (i.e. capacitance response) in calf circumference during LBNP at $-30 \mathrm{mmHg}(0.157 \pm 0.025 \%)$ was greater $(P$ $=0.002)$ than that at $-15 \mathrm{mmHg}(0.102 \pm 0.018 \%)$. The rates of decrease in arm circumference from 3 to $10 \mathrm{~min}$ during LBNP were $-0.0015 \pm 0.0004 \% / \mathrm{min}$ at $-15 \mathrm{mmHg}$ and $-0.0014 \pm 0.0008 \% / \mathrm{min}$ at $-30 \mathrm{mmHg}(P=0.79)$. However, the rate of increase in calf circumference from 3 to $10 \mathrm{~min}$ during LBNP at $-30 \mathrm{mmHg}(0.0078 \pm 0.0008 \% / \mathrm{min})$ was greater $(P<0.01)$ than that at $-15 \mathrm{mmHg}(0.0030 \pm 0.0007 \% / \mathrm{min})$.

A

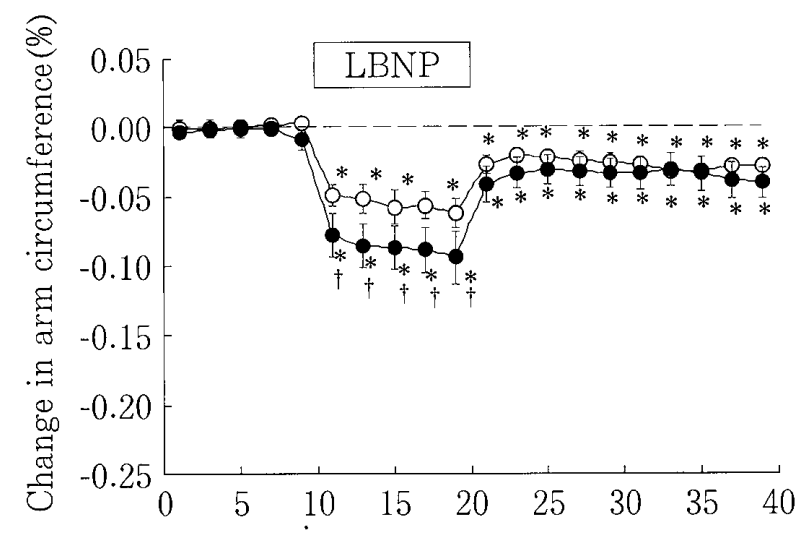

$\mathrm{B}$

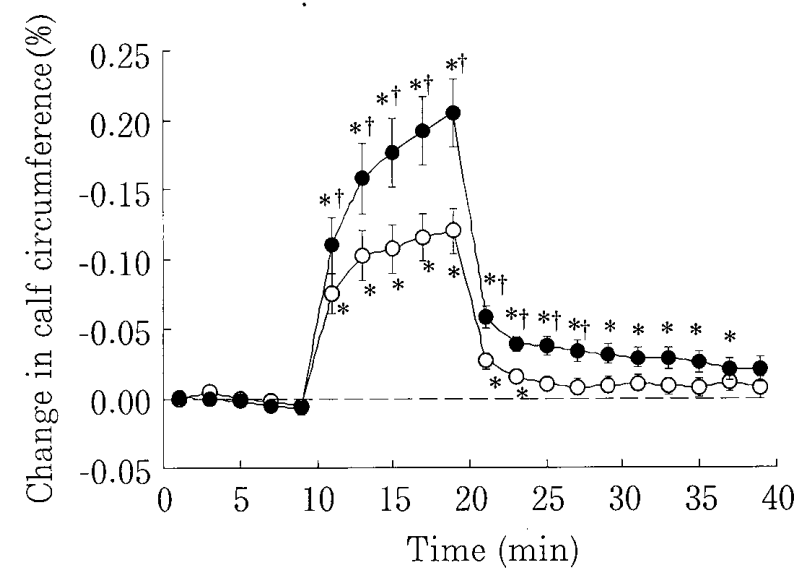

Fig. 2. Changes in circumference in the upper arm (A) and calf (B) during LBNP at -15 and $-30 \mathrm{mmHg}$. $*: P<0.05$ vs the corresponding baseline control, $\uparrow: P<0.05$ vs $-15 \mathrm{mmHg},-0-:-15 \mathrm{mmHg},-\bullet-:-30$ $\mathrm{mmHg}$. 

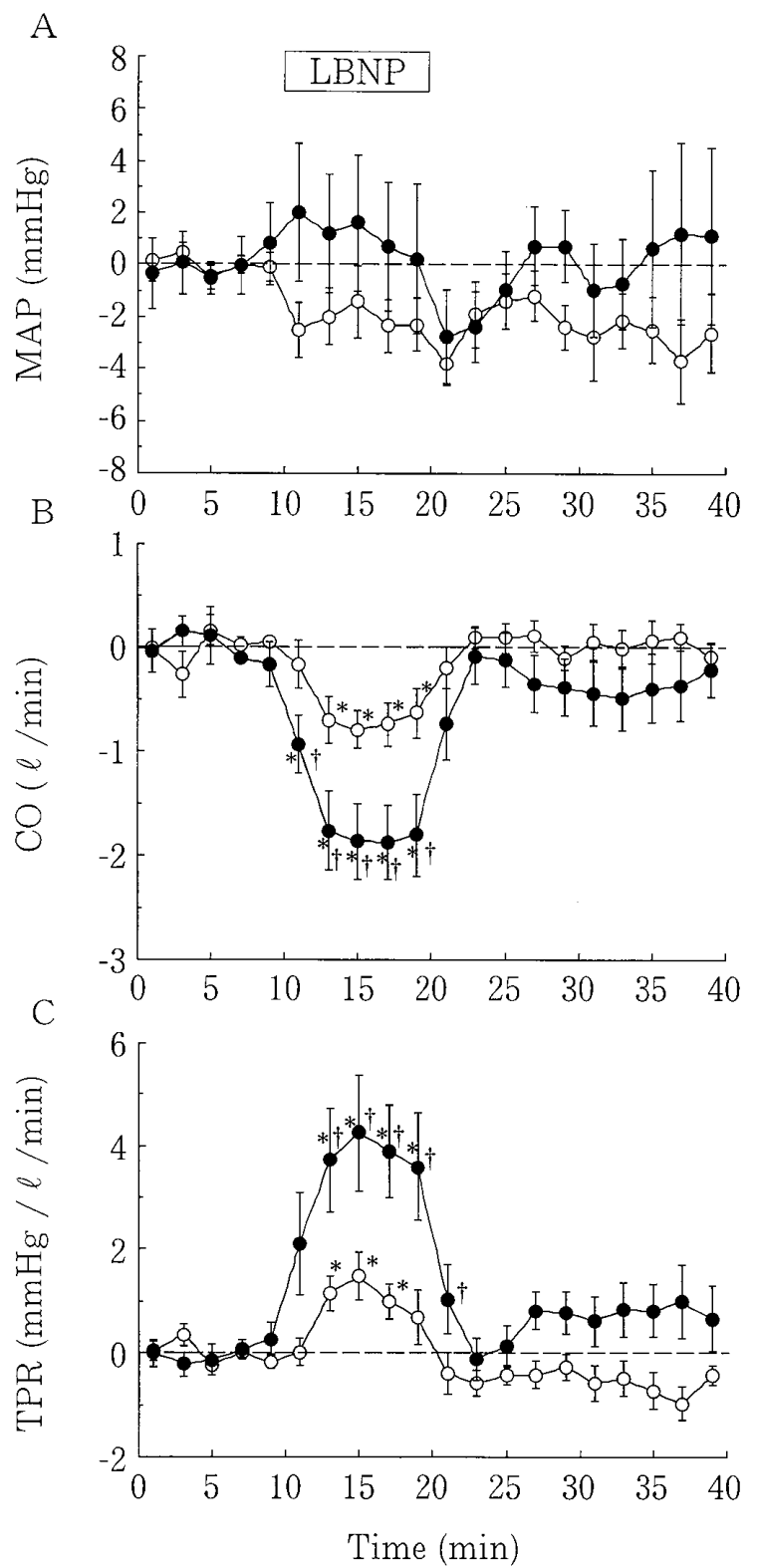

Fig. 3. Changes in mean arterial pressure (MAP), cardiac output (CO) and total peripheral resistance (TPR) during LBNP at -15 and $-30 \mathrm{mmHg}$. $*: P<0.05$ vs the corresponding baseline control, $\uparrow: P<0.05$ vs -15 $\mathrm{mmHg},-\circ:-15 \mathrm{mmHg},-\bullet:-30 \mathrm{mmHg}$.

The average values of MAP $(81.5 \pm 1.9 \mathrm{mmHg}), \mathrm{CO}(7.4 \pm 0.5 \ell / \mathrm{min})$ and TPR $(11.9 \pm 0.8$ $\mathrm{mmHg} / \ell / \mathrm{min}$ ) during the control periods were not significantly different between the two LBNP conditions. As shown in Fig. 3, MAP was not changed significantly by LBNP. LBNP decreased $\mathrm{CO}$ and increased TPR in an intensity-dependent manner. 


\section{Discussion}

The primary intention of the present study was to observe the changes in transcapillary fluid loss (or gain), using a continuous measuring technique during LBNP at different levels. As in a previous report [7], we observed a transient hemodilution prior to hemoconcentration in the early phase of LBNP, and a further hemoconcentration immediately after LBNP. The major findings from the present study are that 1) the LBNP-induced hemoconcentration was greater at $-30 \mathrm{mmHg}$ than at $-15 \mathrm{mmHg}$, while the hemodilution at the start of LBNP did not differ between the intensities, and 2) the response time of the peak hemodilution and hemoconcentration did not differ between the two intensities.

Rapid changes in the volume in the upper arm and calf at the start of LBNP indicate mobilization of blood from the upper body to the lower body. The central hypovolemia resulting from the blood mobilization induced a decrease in CO. The rapid shift in blood (i.e. venous capacitance response) in the early phase of LBNP was clearly dependent on the intensity (Fig. 2).

Slower and continuous decreases in the volume in the upper arm during LBNP indicate a transcapillary fluid shift from the extra- to the intra-vascular space. It has been thought that the absorption of fluid via capillary walls plays a role in maintaining central blood volume during orthostatic stress $[11,16]$. The fluid absorption is caused by a decrease in capillary pressure as a consequence of sympathetic $\alpha$ - and $\beta$-mediated precapillary vasoconstriction [17]. The absorptive response of fluid evaluated using plethysmography did not differ between -15 and $-30 \mathrm{mmHg}$ LBNP. Moreover, contrary to our hypothesis, the initial reduction in $\rho_{\mathrm{b}}$ during LBNP did not differ between the two levels, although the increase in TPR was intensity-dependent. The findings obtained from plethysmography show that both transcapillary fluid absorption in the arms and transcapillary fluid extraction in the legs continued during 10-min LBNP. The increases in $\rho_{\mathrm{b}}, \rho_{\mathrm{p}}$ and Hct with LBNP indicate that the hemoconcentration effect in the legs prevails over the hemodilution effect in the arms during and after LBNP. The reason the initial reduction in $\rho_{\mathrm{b}}$ did not show an intensity-dependence may be that the hemodilution effect in the arms counteracted by the hemoconcentration effect in the legs was associated with changes in transmural pressure in the legs during LBNP in an intensity-dependent manner. It is possible that an LBNP greater than $30 \mathrm{mmHg}$ induces a more pronounced reduction in $\rho_{\mathrm{b}}$ than that observed in the initial phase of LBNP in this study, because transcapillary fluid absorption increased with increasing LBNP from 15 to $60 \mathrm{cmH}_{2} \mathrm{O}$ [18]. In the preliminary studies, however, we had difficulty in collecting blood during LBNP greater than $30 \mathrm{mmHg}$ because of an intense venoconstriction in the arm. This is a limitation in the method.

The rapid recovery in circumference in the arms and legs immediately after cessation of LBNP suggests a sudden redistribution of blood from the lower body into the central parts of the circulation. This redistribution of blood triggers a further increase in $\rho_{\mathrm{b}}$ immediately after LBNP. Furthermore, the increased baroreceptor loading that occurrs with the redistribution of blood induces a decrease in sympathetic nervous activity [19], resulting in a decrease in precapillary vascular tone and consequently increased microvascular filtration 
pressure. The fluid extraction effect also contributes to further hemoconcentration after LBNP.

In the present study, the $\rho_{\mathrm{p}}$ during LBNP increased in a similar manner to $\rho_{\mathrm{b}}$ with a constant $\rho_{\mathrm{e}}$. The increase in $\rho_{\mathrm{p}}$ probably resulted from the protein-poor fluid shift into the

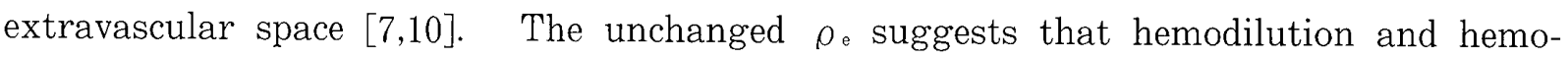
concentration were not a result of the fluid shift across the erythrocyte membranes. Therefore, it is important to note that BV is changed by the net intravascular movement of relatively protein-poor fluid during LBNP.

In conclusion, hemodilution in the early phase of LBNP similarly occurred at light $(-15$ $\mathrm{mmHg}$ ) and moderate levels $(-30 \mathrm{mmHg})$, whereas hemoconcentration induced by LBNP clearly showed intensity-dependent changes with no change in response time.

\section{Acknowledgements}

The technical help of Mr Monji K and Mr Sogabe Y is greatly appreciated. Appreciation is also expressed to the subjects who participated in this project.

\section{References}

1. Blomqvist CG \& Stone HL (1986): Cardiovascular adjustments to gravitational stress. In : Handbook of Physiology. The Cardiovascular System. Peripheral Circulation and Organ Blood Flow. Bethesda, MD: Am Physiol Soc ; Sect 2, Vol 3, Pt 2, Chap 28, $1025-$ 1063

2. Convertino VA (2001): Lower body negative pressure as a tool for research in aerospace medicine and military medicine. J Gravit Physiol 8: 1-14

3. Cooke WH, Ryan KL \& Convertino VA (2004): Lower body negative pressure as a model to study progression to acute hemorrhagic shock in humans. J Appl Physiol 96: 12491261

4. Wolthuis RA, Bergman SA \& Nicogossian AE (1974): Physiological effects of localy applied reduced pressure in man. Physiol Rev 54: 566-595

5. Lundvall J, Bjerkhoel P, Edfeldt H, Ivarsson C \& Länne T (1993): Dynamics of transcapillary fluid transfer and plasma volume during lower body negative pressure. Acta Physiol Scand 147: 163-172

6. Loeppky JA, Kobayashi Y, Venters MD \& Luft UC (1979): Effects of regional hemoconcentration during LBNP on plasma volume determinations. Aviat Space Environ Med 50: 763-767

7. Hinghofer-Szalkay H, Könik EM, Sauseng-Fellegger G \& Zambo-Polz C (1992): Biphasic blood volume changes with lower body suction in humans. Am J Physiol Heart Circ Physiol 263: H1270-H1275

8. Hinghofer-Szalkay H (1986): Method of high-precision microsample blood and plasma mass densitometry. J Appl Physiol 60: 1082-1088

9. Kenner T, Leopold H \& Hinghofer-Szalkay H (1977): The continuous high-precision 
measurement of the density of flowing blood. Pflügers Arch 370: 25-29

10. Hinghofer-Szalkay H, Haas G, Oser H \& Kenner T (1989): Monitoring fluid shifts in humans: application of a new method. Aviat Space Environ Med 60: 23-28

11. Mellander S \& Öberg B (1967): Transcapillary fluid absorption and other vascular reactions in the human forearm during reduction of the circulating blood volume. Acta Physiol Scand 71: 37-46

12. Endo Y, Torii R, Yamazaki Y, Sagawa S, Yamauchi K, Tsutsui Y, Morikawa T \& Shiraki $\mathrm{K}$ (2001): Water drinking causes a biphasic change in blood composition in humans. Pflügers Arch 442: 362-368

13. Yamazaki F, Endo Y, Torii R, Sagawa S \& Shiraki K (2000): Continuous monitoring of change in hemodilution during water immersion in humans: effect of water temperature. Aviat Space Environ Med 71: 632-639

14. Kubicek WG, Karnegis JN, Patterson RP, Witsoe DA \& Mattson RH (1966): Development and evaluation of an impedance cardiac output system. Aerosp Med 37: 1208-1212

15. Hinghofer-Szalkay H \& Moser M (1986): Fluid and protein shifts after postural changes in humans. Am J Physiol Heart Circ Physiol 250: H69-H75

16. Lundvall $J$ \& Länne $T$ (1989): Large capacity in man for effective plasma volume control in hypovolaemia via fluid transfer from tissue to blood. Acta Physiol Scand 137: 513520

17. Maspers M \& Björnberg J (1991): Beta $_{2}$-adrenergic attenuation of capillary pressure autoregulation of during haemorrhagic hypotension, a mechanism promoting transcapillary fluid absorption in skeletal muscle. Acta Physiol Scand 142: 11-20

18. Olsen H, Hulthèn UL \& Länne T (1999): Reduced transcapillary fluid absorption from skeletal muscle and skin during hypovolaemia in insulin-dependent diabetes mellitus. J Intern Med 246: 477-488

19. Yamauchi K, Tsutsui Y, Endo Y, Sagawa S, Yamazaki F \& Shiraki K (2002): Sympathetic nervous and hemodynamic responses to lower body negative pressure in hyperbaria in men. Am J Physiol Regulatory Integrative Comp Physiol 282: R38-R45 
下半身陰圧負荷中の血液量と四肢容量の変化の連続的モニタリング

山崎 文夫 ${ }^{1}$, 白木 啓三 ${ }^{2}$, 遠藤 豊 $^{3}$, 佐川 寿栄子 ${ }^{4}$

'産業医科大学 産業保健学部 臨床病態学講座

${ }^{2}$ 産業医科大学 医学部 第二生理学講座

${ }^{3}$ 国際医療福祉大学 小田原保健医療学部

${ }^{4}$ 九州共立大学 スポーツ学部

要

旨：下半身に陰圧(LBNP)を負荷すると,下肢に静脈血が貯留し,血液量 $(\mathrm{BV})$ は減少する. 本研 究の目的は,LBNP中のBV と四肢容量の動的変化を調查することであった. 健康な 8 名の 男性被検者を対象として, -15 と $-30 \mathrm{mmHg}$ のLBNP中に血液密度 $\left(\rho_{\mathrm{b}}\right)$ を連続測定した. $\rho_{b}$ 測定のため,40 分間の測定期間中 (10 分間のコントロール期,10 分間のLBNP期, 20 分間の回復期)に, 血液を肘前静脈から連続的に採取した. 密度は機械的振動法で 測定し,上腕と下腿の周囲長の変化はストレインゲージプレチスモグラフィーで測 定した. ○はLBNPの開始に伴って減少してから増加に転じた. $-15 \mathrm{mmHg}$ 負荷時 の $\rho_{\mathrm{b}}$ の最大減少值 $(-0.35 \pm 0.04 \mathrm{~g} / \ell)$ は $-30 \mathrm{mmHg}$ 負荷時のそれ $(-0.42 \pm 0.05$ $\mathrm{g} / \ell)$ と差がなかった $(P=0.47) . \mathrm{LBNP}$ 開始から $\rho_{\mathrm{b}}$ の最大減少までの時間 $(2.9 \pm 0.3$ $\min )$ は, -15 と-30 $\mathrm{mmHg}$ 負荷間で差がみられなかった $(P=0.50)$. いずれの負荷 強度においても, $\rho_{\mathrm{b}}$ はLBNP終了後 $2.5 \pm 0.2$ 分間増加し続けた後にコントロールレ ベルまで回復した. $-30 \mathrm{mmHg}$ のLBNP後の $\rho$ 。の最大増加 $(1.34 \pm 0.07 \mathrm{~g} / \ell)$ は $-15 \mathrm{mmHg}$ 負荷後のそれ $(0.57 \pm 0.06 \mathrm{~g} / \ell)$ より有意に大きかった $(P<0.001) . \mathrm{LB}$ NP中,負荷強度に依存して上腕周囲長は減少し,下腿周囲長は増加した.これらの結 果から,LBNPは強度依存性にBVを減少させるが,その最大減少出現時間は強度閒で 差がないこと,LBNP初期の血液希釈効果には強度の影響が見られないこと,およびL BNPは強度依存性に上半身から下半身へ血液の移動を引き起こすことが示唆された.

キーワード：血液密度, 血漿密度, 血液量, 重力ストレス, 体液吸収.

J UOEH (産業医大誌) 29 (3) : 235-245（2007） 